6 Ерремова Н.Ф., Сучкова Л.А., Платонова И.Ю. Формирование портфолио студента как современная оценочная технология. - Ростов-на-Дону, 2018. - 55 с.

7 Qvortrup A., Keiding T.B. Portfolio assessment: production and reduction of complexity // Assessment \& Evaluation in Higher Education. - 2015. Vol. 24(3). - P.407-419.

8 Плахина Л.Н., Дианова Ю.А. Методика создания электронного портфолио в системе подготовки студента к будущей педагогической деятельности // Вектор науки Тольяттинского государственного университета. Серия: Педагогика, психология. - 2014. - №4(19). - C.138-140.

9 Batson T., Coleman K.S., Chen H.L., Watson C.E., Rhodes T.L., Harver A. Field guide to eportfolio. Washington, DC: Association of American Colleges and Universities, 2017. - 119 p.

Reference:

1. State Program for the development of Education and Science of the Republic of Kazakhstan for 20202025. https://www.zakon.kz/5002441-utverzhdena-gosudarstvennaya-programma.html

2. VillarroelV., BloxhamS., BrunaD., BrunaC., Herrera Seda C. Authentic assessment:creating ablueprint for coursedesign // Journal Assessment\&Evaluation in Higher Education.-2018.-Vol.43(5).-P.840-854.

3. Orynbayeva U.K., Zhaukumova Sh. S. Smagulov K.D evelopment of pedagogical reflectionin the professional trainingofa teacher of foreign languagell Bestnik KazNU Hy..-2018.-№2(55)-C.26-33.

4.HoferB.K. Shapingtheepistemologyofteacherpracticethroughreflectionandreflexivity //Educational Psychologist.-2017.-Vol.52(4).-P.299-306.

5. Evaluation of educational results in the process of forming a student's portfolio /Shekhonin A. A., Tarlykov V. A., Kleshcheva I. V., Bagautdinova A. Sh. - St. Petersburg: NIUITMO, 2014. - 81s.

6. Efremova N. F., Suchkova L. A., Platonova I. Yu. Formation of a student's portfolio as a modern evaluation technology. - Rostov-on-Don, 2018. - 55 p.

7. QvortrupA., KeidingT.B. Portfolio assessment:production and reduction of complexity//Assessment\& Evaluationin Higher Education.-2015.Vol.24(3).-P.407-419.

8. Plakhina L. N., Dianova Yu. A. Methodology for creating an electronic portfolio in the system of preparing a student for future pedagogical activity //Vector of Science of Tolyatti State University. Series: Pedagogy, psychology. - 2014. - № 4 (19). - Pp. 138-140.

9. Batson T.,Coleman K.S.,Chen H.L.,Watson C.E., Rhodes T.L.,Harver A.Fieldguidetoe portfolio.Washington, DC: Association of American Colleges and Universities,2017.-119p.

МРНТИ 14.07. 07

https://doi.org/10.51889/2020-3.1728-5496.12

\author{
R.S. Zheldibayeval, A.Zh. Sapargaliyeva ${ }^{l}$ \\ ${ }^{I}$ NJSC «Zhetysu University named after I.Zhansugurov», \\ Taldykorgan, Kazakhstan
}

\title{
CONDITIONS FOR THE DEVELOPMENT OF PROFESSIONAL COMPETENCIES OF FUTURE PEDAGOGUE-PSYCHOLOGISTS IN THE CONTEXT OF GLOBALIZATION
}

\begin{abstract}
Today, there is ample evidence that the priority task of education professionals is to preserve and strengthen the mental health of children, taking into account different needs and opportunities. In accordance with the modern qualification needs in higher educational institutions, in order to prepare targeted educational psychologists, it is necessary to organize a high level of practice for students who form professional competence. They need to effectively perform labor functions in their future professional activities. As the preliminary analysis shows, there are many ideas in this area in the world. These ideas are aimed at addressing these priorities.

This article discusses the conditions for the development of professional competencies of future pedagogue-psychologists in the context of globalization. Particular attention is paid to the current status of
\end{abstract}


pedagogue-psychologists working at schools and the level of readiness of Kazakhstani universities in the preparation of future pedagogue-psychologists. The experience of foreign universities in this direction is also described, conducting a comparative analysis of the achievements in the field of practical psychology in our country and foreign countries.

Keywords: professional competencies, higher education, pedagogue-psychologists, new educational standards, globalization.

\author{
Р.С. Желдибаева ${ }^{I}$, А.Ж. Сапаргалиева ${ }^{l}$ \\ ${ }^{1}$ «I.Жансүгіров атындавы Жетісу университеті» \\ коммерииялық емес құовамдық ұйымы, \\ Талдықорган қ., Қазақстан
}

\title{
ЖАһАНДАНУ ЖАҒДАЙЫНДА БОЛАШАҚ ПЕДАГОГ-ПСИХОЛОГТАРДЫН КӘСІБИ КҰЗІРЕТТІЛІГІН ДАМЫТУ ШАРТТАРЫ
}

\begin{abstract}
Аң̧датпа
Бүгінгі таңда білім беру жүйесіндегі мамандарда балалардыңәр түрлі қажеттіліктері мен мүмкіндіктерін ескере отырып, психикалық денсаулығын сақтау және нығайту міндеті бар екендігіне көптеген дәлел бар. Қазіргі жоғары оқу орындарындағы мансаптық қажеттіліктерге сәйкес, мақсатты педагог-психолог болу үшін кәсіби құзіреттілігінқалыптастыратын білімгерлер үшін жоғары деңгейлі практика ұйымдастыру қажет. Оларға болашақ кәсіби қызметінде еңбек функцияларын тиімді орындау қажет. Алдын-ала талдау көрсеткендей, әлемде бұл салада көптеген идеялар бар. Бұл идеялар осы басым міндеттерді шешуге бағытталған.
\end{abstract}

Бұл мақалада жаһандану жағдайында болашақ педагог-психологтардың кәсіби құзыреттіліктерін дамыту шарттары қарастырылады. Мектептерде қызмет атқаратын педагог- психологтардың қазіргі статусына және болашақ педагог-психологтарды даярлауға қазақстандық жоғары оқу орындарының дайындығына ерекше назар аударылады. Осы бағыттағы шетелдік жоғары оқу орындарының тәжірибесі мен біздің еліміздегі және шет елдердегі практикалық психология саласындағы жетістіктерге салыстырмалы талдау жасай отырып сипатталған.

Түйін сөздер: кәсіби құзіреттіліктер, жоғарғы білім, педагог-психолог, жаңа білім стандарттары, жаһандану.

\author{
Р.С. Желдибаева ${ }^{1}$ А.Ж. Сапаргалиева ${ }^{1}$ \\ ${ }^{1}$ НАО «Жетысуский университет им. И.Жансугурова», \\ 2. Талдыкорган, Казахстан

\section{УСЛОВИЯ РАЗВИТИЯ ПРОФЕССИОНАЛЬНЫХ КОМПЕТЕНЦИИ БУДУЩИХ ПЕДАГОГОВ-ПСИХОЛОГОВ В УСЛОВИЯХ ГЛОБАЛИЗАЦИИ}

\begin{abstract}
Аннотация
На сегодняшний день есть множество доказательств того, что приоритетной задачей специалистов системы образования является сохранение и укрепление психического здоровьядетей с учетом различных потребностей и возможностей. В соответствии с современными квалификационными потребностями в высших учебных заведениях, для того, чтобы подготовить целенаправленных педагогов-психологов, необходимо организовать высокий уровень практики для студентов, формирующих профессиональную компетентность. Им необходимо эффективно выполнять трудовые функции в будущей профессиональной деятельности. Как показывает предварительный анализ, в мире существует множество идей в этой области. Эти идеи направлены на решение этих приоритетных задач.

Данная статья рассматривает условия развития профессиональных компетенции будущих педагогов-психологов в контексте глобализации. Особое внимание уделяется нынешнему статусу педагогов-психологов, работающих в школах и уровню готовности казахстанских ВУЗов при
\end{abstract}


подготовке будущих педагогов-психологов. Также описывается опыт зарубежных ВУЗов в данном направлении, проводя сравнительный анализ достижении в области практической психологии в нашей стране и зарубежных странах.

Ключевые слова: профессиональные компетенции, высшее образование, педагог-психолог, новые образовательные стандарты, глобализация.

Introduction. It is widely known that today Kazakhstan is actively introducing updated educational content. In a positive scenario, students will finally be able to move away from mechanical memorization of material that in the future will not be useful for them in their professional activities, also they will receive more academic freedom, while being able to develop as a person, reveal their talents, increase their competitiveness, as well as correctly and independently search for information and develop critical thinking. To achieve all of these goals, it is necessary to take into account the psychophysiological and age-related characteristics of personality development, thatis why the activities and professionalism of pedagoguepsychologists in schools are more relevant than ever.

Methodology.The main method of the article under consideration is the method of comparative analysis. Scientific works of foreign, Russian and Kazakhstani scholars on the given topic have been thoroughly examined and analyzed in order to figure out their main ideas and include them in this article.

The results of American scientistsstudy in the field of psychology show that often a bachelor's degree graduate does not have enough competence to immediately start working, assuming a huge responsibility. As for instance, in the United States, as part of their education and training, school psychologists take courses in psychology and training to be able to interact with students, families, teachers, administrators, and other mental health professionals. To be allowed to work as a school psychologist in the United States, a person must complete a four-year bachelor's degree and graduate from an accredited psychology program at a College or University, whereas in Kazakhstan it is enough to have a bachelor's degree.

American graduates must also complete an internship of 1200 hours upon completion of their studies at the University. If a student wants to get a doctorate in school psychology, they will have to complete a 1500hour internship during their studies in addition to their dissertation to get their degree.

All fifty States require professional licensing of school psychologists. In addition to state licensing, there are many professional boards and organizations related to this field, including the national Board of school psychology certification and the national Association of school psychologists. These organizations oversee the professional accreditation and certification of school psychologists and school psychological education programs.

Research results. Unfortunately, in our country, we can not yet speak about such a high level of training of pedagogues-psychologists. This fact can be justified by the argument that this specialty in our country appeared relatively recently, because officially psychologists were introduced to the staff of Kazakh schools only in 1987 and practical psychology of education began to develop actively in our country. To date, many schools have introduced a staff unit «pedagogues-psychologist», therefore, higher education institutions train specialists of educational program 6B011 - «Pedagogy and psychology» specifically for working in educational institutions. However, it is often difficult for a young specialist to find and occupy a niche in a specific closed school system when they come to school. It takes a lot of time to adapt and understand the system of an educational institution, to determine the direction of their work. False or distorted ideas (stereotypes) about who a psychologist is, what he does, exist in modern schools, and also significantly slow down the pace of development of psychological activity of a pedagogues-psychologist.

In addition, it should be noted that Kazakhstan has undergone rapid social and educational transformations after being part of the Soviet Union for many years, having regained its independence in 1991. Along with these changes, major reforms were carried out in the field of education. The system and quality of higher education, including the training of school pedagogue-psychologists, has changed radically since Kazakhstan joined the Bologna process in 2010 and signed the Bologna Declaration. Universities participating in this process have formed a unified curriculum, which makes their training more uniform allowing graduates to work not only in their home country but also around the world. Moreover, the graduate model of today is very different from the past years. Let us start with the fact that a graduate must be fluent in foreign languages, not only in order to be demanded specialist abroad, but also in order to be able to read foreign literature on their specialization, participate in various international conferences, seminars, trainings, and possibly conduct joint research with their foreign colleagues. After all, in the modern world, it is so important to keep up with the times and be aware of all the innovations in your professional field.

As we have already underlined, the professional activity of pedagogue-psychologists in schools in the 
current conditions of educational sphere is more relevant than ever and a huge role in the development of this direction is played by the readiness of HEI (material and technical base, quality of education, the level of training of teachers) in the preparation of future pedagogue- psychologists. Psychological services, as well as the training of those who provide them, are socioculturally embedded in each society and are thus influenced by its history and current status. Caterrall emphasized four qualities that influence the development of psychological services in schools: the level of development of the country's education system, teacher training and quality education, the level of special education services, and the level of psychology [1, p.177]. These and other qualities have been confirmed by others (Oakland and Jimerson, 2007). The impact of these and other countries on the quality of school psychologist training should be taken into account. Thus, understanding the training of school psychologists requires us to consider both early and current social conditions that affect education and psychology [2, p.453].

Recently, new educational standards focus on assessing the readiness of a future specialist not by the level of development of a specific content of the educational program, but by the level of formation of certain competencies. In this regard, there is a need to apply innovative approaches to the training of future specialists. As noted by the doctor of psychological Sciences V.I. Dolgova, «the most important characteristic of the capabilities of the subject of innovative activity is professional activity» [3, p. 19].

The level of personal activity in training, according to A.A. Verbitsky, «is determined by its basic logic, as well as the level of development of educational motivation» [4, p.288]. The competence approach contributes to the development of students' activity and motivation, as well as to the successful solution of educational tasks. This activates the activity of teachers to apply active and interactive methods and tools of teaching in the educational process.

The use of active teaching methods by N.A. Zimina is noted as one of the ways to improve the professional competence of psychologists, which the scientist refers to training seminars, business games, and discussion methods [5, p.1].

In this thesis she revealed the possibility of formation of the elements of the competencies case- method and shows that the case method is an integrative method of learning, «aimed at strengthening ties between the components of competence, such as knowledge, skills, experience, motivation, values, personal qualities», the introduction of which allows to solve educational tasks of the higher school of formation the competence of a specialist.

It should be noted that the experience of using interactive teaching methods in the educational process of the University is revealed in the publications of the author, who notes that interactive methods are aimed at organizing active interaction of all participants in the educational process and the presence of feedback between them.

Based on the above, we will consider the following of the psychological and pedagogical conditions for the formation of professional competence of future pedagogue-psychologists as the use of interactive teaching methods in the educational process.

Interactive («Inter» - is mutual, « act »- to act) - means to interact, to be in the mode of conversation, dialogue with someone. Interactive and active methods have a lot in common. In contrast to active methods, interactive methods are focused on a broader interaction of students not only with the teacher, but also with each other and on the dominance of students' activity in the learning process. Interactive methods are understood as methods that are focused on a broader interaction of students not only with the teacher, but also with each other [3].

In this case, the task of the teacher becomes the development of students' activity and their initiative, the organization of their joint group and inter-group activities, dialogical communication.

In the understanding of interactive interaction in the classroom, we refer to the scheme of E.A. Reutova, which is shown in figure [6, p. 58].

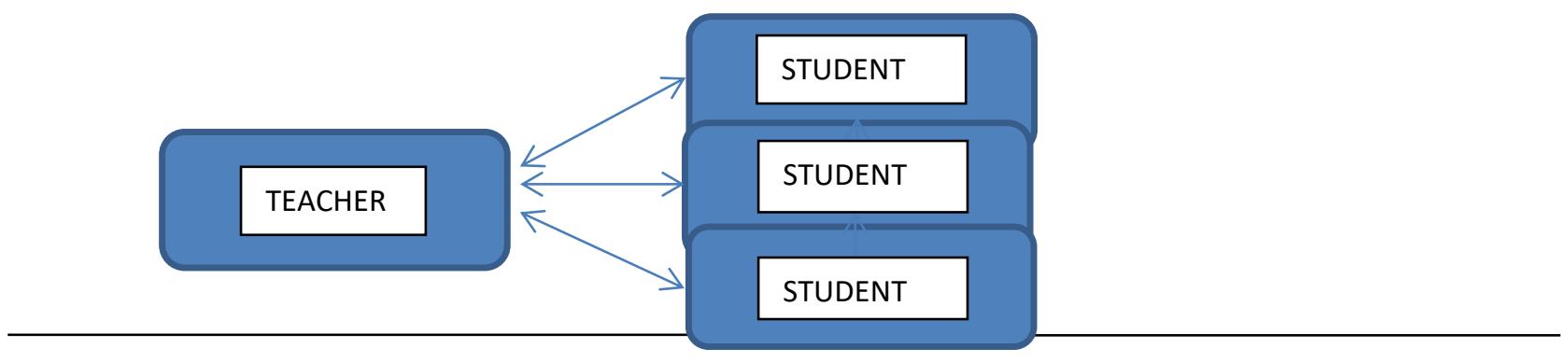


Fig.-1. Interaction of participants in the educational process when implementing interactive methods

According to E.A. Reutova, interactive methods «are focused on a broader interaction of students not only with the teacher, but also with each other and on the dominance of students 'activity in the learning process» [6]. Among the interactive teaching methods, E. A. Reutova includes game (business educational game, role-playing game, psychological training) and non-game (case-study analysis, group discussions, brainstorming, cooperative learning methods, interactive lectures). Interactive teaching methods, in contrast to active ones, are aimed at changing the nature of relationships between participants in the educational process and involve all participants in the educational process.

Research discussion. Domestic modern scientists also pay a great attention to the conditions for development of professional competence of future pedagogue-psychologists. Thus, A.Sapargaliyeva after analyzing numerous sources on the problem professional activity of pedagogue -psychologists in her thesis work claims thatthe psychological service in education looks like a single vertical structure in educational space of the country - psychological service of individual educational institutions, city and regional centers of psychological support educational services, regional centers of psychological services education-Ministry of education and science [7, p.27]. Psychological service of any educational institution is considered in the unity of three aspects: scientific, applied and practical.

The goals of the psychological service are determined depending on the type educational institution, from the concept implemented in it, or educational program. In his professional activity, the pedagogical psychologist performs the following main types of work: psychological education, psychological prevention, psychological diagnostics, psychological correction, psychological counseling. Each of these types of work can be the main one depending on the problem, which is decided by the pedagogue-psychologist, depending on the specifics of the institution where he / she isit works.

Professional vocation is a complex phenomenon that it is characterized by a complex of personal qualities of the specialist, his socio-psychological readiness to implement the functions of a pedagogue-psychologist asspecialist helping professions.

If we consider the professional activities of educational psychologist as specialist the helping professions in our view it is one of the most multifaceted and time-consuming professional activities, diversity of issues and tasks.

Professional skills of a pedagogue-psychologist cover a spectrum typical of the Humanities professions, and include:

- communication skills (knowledge of communication culture, skills communication optimizations, etc.);

- activity-role skills (establishing partnerships, changing role positions);

- organizational skills (coordination of efforts of various social groups customer (child) problem solving services));

- design skills (ability to emotional and cognitive other people's knowledge);

- empathic skills and possession of means to influence others people.

However, the success of the pedagoguepsychologist as a specialist helping professions it depends not only on the acquired system of knowledge and skills, but also is determined bypersonal qualities. These include such qualities as emotional stability, intuition, empathy, sociability, goodwill, creativity, the ability to solve a problem for a long time problems, high level of social claims, etc [7.p.28].

Among the mandatory qualities and skills of apedagogue -psychologist: ability and empathy, patience, kindness, willingness to help others, psychological sensitivity, delicacy and tact; humanity and humanism; charity; high spiritual culture and morality; ability to be interesting to others and informal in working with children; ability to protect the client's human dignity; commitment to continuous improvement of professional knowledge; honesty, moral cleanliness in professional Affairs; compliance with the ethics of relations with people, etc.

Conclusion. Conditionsfor the development of professional competencies of future pedagoguepsychologiststhat influence the development of psychological services in schoolscan be considered as follows: the level of development of the country's education system, teacher training and quality education, the level of special education services, and the level of psychology. 
Абай атындавы ҚазҰПУ-ц ХАБАРШЫСЫ «Педагогика вылымыдары»» сериясы, №3(67), 2020 ж.

Thus, particular attention should be paid to the current status of pedagogue-psychologists working in schools and the level of readiness of Kazakhstani universities in the preparation of future pedagoguepsychologists. The experience of foreign universities in this direction should be also taken into consideration, conducting a comparative analysis of the achievements in the field of practical psychology in our country and foreign countries.

\section{References:}

1 Catterall, C. (19 79). Factors affecting the development of schoolpsychological services. In C.Catterall (Ed.), Psychology in the schoolin international perspective: Vol. 3 (pp. 177-178).

2 Oakland, T.\&Jimerson, S. (2007). School psychology internationally: A retrospective view and influential conditions. In S.Jimerson, T.Oakland\& P.Farrell (Eds.). The handbook of international school psychology (pp. 453-462).

3 Dolgova, V. I. Invariance of professionally important qualities [Electronic resource]: monograph / V.I. Dolgova, V.K. Shayakhmetova. - Mode of access: http://elib.cspu.ru/xmlui/handle/123456789/351

4 Verbitsky, A.A. Invariants of professionalism: problems of formation: monograph / A.A. Verbitsky, M.D. Ilyazova. - Moscow: Logos, 2011. - 288 p.

5 Zimina, N.A. Psychological conditions of optimization professional competence of psychologists in solving behavioral problems of young children [Electronic resource]: autoref. on the Internet. academic step. Cand. the course of studies. Sciences: 19.00.07-pedagogical psychology / Natalia Alexandrovna Zimin. - Mode of access: http://dlib.rsl.ru/viewer/01002646787\#?page=1.

6 Reutova, E.A. Application of active and interactive methods of teaching in the educational process of higher education. - Novosibirsk: Publishing house of Novosibirsk state agrarian University, 2012. - 58 p.

7 Sapargaliyeva A. Improvement of professional training of the pedagogue-psychologist as a specialist of helping professions. - Almaty, 2015. - 148 p.

МРНТИ 14.37.27

https://doi.org/10.51889/2020-3.1728-5496.13

К.С. Ахметкаримова ${ }^{l}$, Р.Ш. Абитаева ${ }^{1}$

${ }^{1}$ Жезказганский университет имени О.А. Байконурова

г. Жезказган, Казахстан

\section{К ВОПРОСУ О ПРОФЕССИОНАЛЬНОЙ ПЕРЕПОДГОТОВКЕ ПЕДАГОГОВ- АССИСТЕНТОВ ДЛЯ ДОШКОЛЬНЫХ УЧРЕЖДЕНИЙ ОБЩЕГО ТИПА В ВУЗЕ}

\section{Аннотаичи}

В статье поднимается вопрос о необходимости переподготовки воспитателей дошкольных организаций к новой должности педагога-ассистента. Отмечаются причины ненадлежащего исполнения профессиональных обязанностей воспитателями в работе с детьми, имеющим особые образовательные потребности. Необходимость переподготовки соискателей на должность педагогапсихолога из воспитателей-практиков в условиях вуза обосновывается внесением последних изменений в Квалификационные характеристики должностей педагогических работников и приравненных к ним лиц. Обращается внимание на то, что большинство педагогов дошкольных учреждений г. Жезказгана не готовы к работе с детьми, имеющими особые образовательные потребности. Для систематической работы с педагогами и детьми данной категорией нужен подготовленный педагогпсихолог. Акцент делается на том, что в условиях реализации новых стандартов дошкольного образования, готовность и способность педагога-ассистента к работе с детьми должна быть нормой. Приводятся предварительные результаты исследования готовности претендентов к работе с дошкольниками, имеющими особые образовательные потребностикак в курсовой период переподготовки в вузе, так и в послекурсовой. Раскрывается роль кафедры в дальнейшей совместной 